Prepared in collaboration with the Missouri Department of Conservation

\title{
Concentrations of Elements in Fish Fillets, Fish Muscle Plugs, and Crayfish from the 2011 Missouri Department of Conservation General Contaminant Monitoring Program
}

Open-File Report 2012-1268 



\section{Concentrations of Elements in Fish Fillets, Fish Muscle Plugs, and Crayfish from the 2011 Missouri Department of Conservation General Contaminant Monitoring Program}

By Thomas W. May, Michael J. Walther, William G. Brumbaugh, and Michael J. McKee

Prepared in collaboration with the Missouri Department of Conservation

Open-File Report 2012-1268 


\section{U.S. Department of the Interior \\ KEN SALAZAR, Secretary \\ U.S. Geological Survey \\ Marcia K. McNutt, Director}

U.S. Geological Survey, Reston, Virginia: 2013

For more information on the USGS — the Federal source for science about the Earth, its natural and living resources, natural hazards, and the environment, visit http://www.usgs.gov or call 1-888-ASK-USGS.

For an overview of USGS information products, including maps, imagery, and publications, visit http://www.usgs.gov/pubprod

To order this and other USGS information products, visit http://store.usgs.gov

Any use of trade, firm, or product names is for descriptive purposes only and does not imply endorsement by the U.S. Government.

Although this information product, for the most part, is in the public domain, it also may contain copyrighted materials as noted in the text. Permission to reproduce copyrighted items must be secured from the copyright owner.

Suggested citation:

May, T.W., Walther, M.J., Brumbaugh, W.G., and McKee, M.J., 2013, Concentrations of elements in fish fillets, fish muscle plugs, and crayfish from the 2011 Missouri Department of Conservation general contaminant monitoring program: U.S. Geological Survey Open-File Report 2012-1268, 12 p. 


\section{Contents}

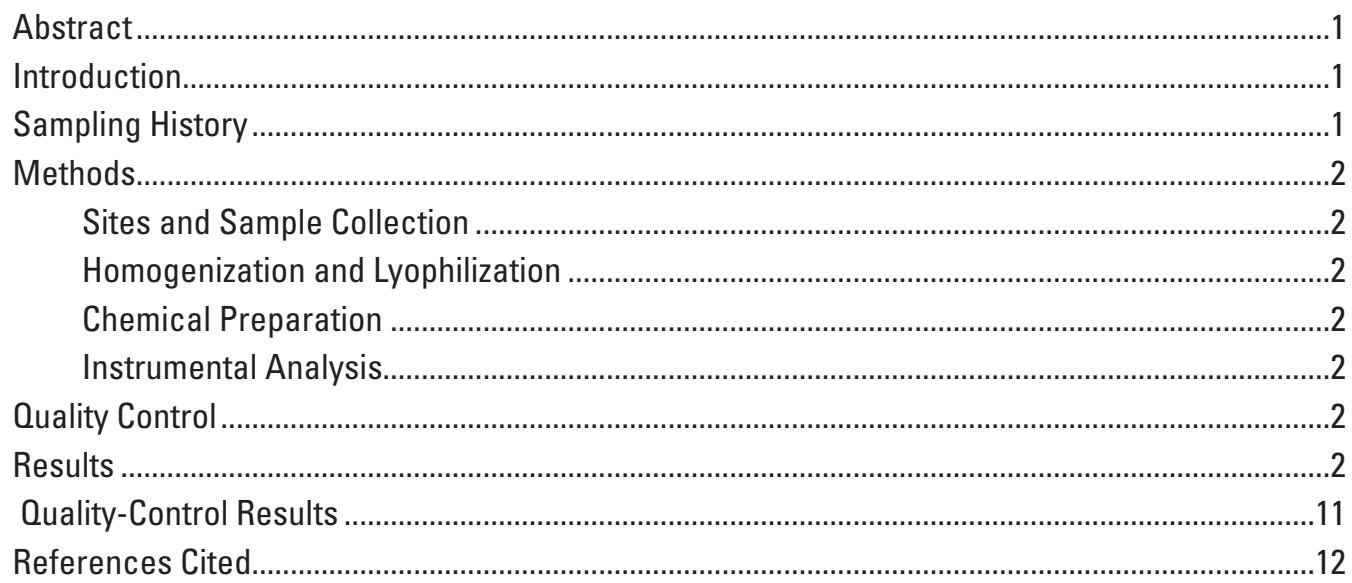

\section{Tables}

1. Missouri collection sites for fish fillets, fish muscle plugs, and crayfish from the 2011 Missouri Department of Conservation General Contaminant Monitoring Program.

2. Percent moisture and dry weight concentrations of calcium, zinc, cadmium, lead, and lead/calcium molar ratios in Missouri Department of Conservation 2011 General Contaminant Monitoring Program fish fillet, fish muscle plug, and crayfish samples.

3. Percent moisture and wet weight concentrations of calcium, zinc, cadmium, and lead in Missouri Department of Conservation 2011 General Contaminant Monitoring Program fish fillet, fish muscle plug, and crayfish samples ..........................6

4. Concentrations of total mercury in fish fillets, fish muscle plugs, and crayfish tissues.. 


\section{Conversion Factors}

\begin{tabular}{lcl}
\hline \multicolumn{1}{c}{ Multiply } & By & \multicolumn{1}{c}{ To obtain } \\
\hline millimeter $(\mathrm{mm})$ & Length & \\
micrometer & 0.03937 & inch (in.) \\
& 0.0000393 & inch (in.) \\
\hline liter $(\mathrm{L})$ & Volume & \\
milliliter $(\mathrm{mL})$ & 33.82 & ounce, fluid (fl. oz) \\
& .034 & ounce, fluid (fl. oz) \\
\hline gram $(\mathrm{g})$ & Mass & \\
milligram $(\mathrm{mg})$ & 0.03527 & ounce, avoirdupois $(\mathrm{oz})$ \\
microgram $(\mu \mathrm{g})$ & .000035 & ounce, avoirdupois $(\mathrm{oz})$ \\
\hline
\end{tabular}

Temperature in degrees Celsius $\left({ }^{\circ} \mathrm{C}\right)$ may be converted to degrees Fahrenheit $\left({ }^{\circ} \mathrm{F}\right)$ as follows: ${ }^{\circ} \mathrm{F}=\left(1.8 x^{\circ} \mathrm{C}\right)+32$

Concentrations of chemical constituents in water are given in nanograms per milliliter (ng/mL).

Concentrations of chemical constituents in solid materials are given in either micrograms per gram $(\mu \mathrm{g} / \mathrm{g})$ dry weight or $\mu \mathrm{g} / \mathrm{g}$ wet weight. 


\title{
Concentrations of Elements in Fish Fillets, Fish Muscle Plugs, and Crayfish from the 2011 Missouri Department of Conservation General Contaminant Monitoring Program
}

\author{
By Thomas W. May', Michael W. Walther' ${ }^{1}$, William G. Brumbaugh', and Michael J. McKee ${ }^{2}$
}

\begin{abstract}
This report presents the results of a contaminant monitoring survey conducted annually by the Missouri Department of Conservation to examine the levels of selected elemental contaminants in fish fillets, fish muscle plugs, and crayfish. Fillet samples of yellow bullhead (Ameiurus natalis), golden redhorse (Moxostoma erythrurum), longear sunfish (Lepomis megalotis), and channel catfish (Ictalurus punctatus) were collected from six sites as part of the Missouri Department of Conservation's Fish Contaminant Monitoring Program. Fish dorsal muscle plugs were collected from largemouth bass (Micropterus salmoides) at eight of the sites, and crayfish from two sites. Following preparation and analysis of the samples, highlights of the data were as follows: cadmium and lead residues were most elevated in crayfish tissue samples from the Big River at Cherokee Landing, with 1 to 8 micrograms per gram dry weight and 22 to 45 micrograms per gram dry weight, respectively. Some dorsal muscle plugs from largemouth bass collected from Clearwater Lake, Lake St. Louis, Noblett Lake, Hazel Creek Lake, and Harrison County Lake contained mercury residues (1.7 to 4.7 micrograms per gram dry weight) that exceeded the U.S. Environmental Protection Agency Water Quality Criterion of 1.5 micrograms per gram dry weight of fish tissue (equivalent to 0.30 micrograms per gram wet weight).
\end{abstract}

\section{Introduction}

The Missouri Department of Conservation (MDC) initiated long-term statewide fish monitoring of environmental contaminants in 1984 with the objective of selecting predator and bottom dwelling species annually from each of 20 to 30 lakes and streams across Missouri to characterize

${ }^{1}$ U.S. Geological Survey

${ }^{2}$ Missouri Department of Conservation concentrations of targeted metals and other chemical contaminants. Actual sites monitored each year vary based on data needs, budgets, and personnel resources. Emphasis is on human health effects from recreational and sport fishing, so study components include fish fillets, composite fillet samples, and sample replication at each site. The MDC has requested the assistance of the U.S. Geological Survey (USGS) for this monitoring program because of past experience with aquatic biota monitoring projects and expertise in the preparation and analysis of aquatic biota for elemental contaminants. For more detailed information on the overall study design or specific sample information, please contact the Missouri Department of Conservation in Columbia, Missouri (http://mdc.mo.gov/ regions/central).

\section{Sampling History}

A shipment of 27 whole-body fish, 25 fish fillets, 48 fish muscle plugs, and 37 crayfish tissues was received by USGS personnel on December 7, 2011. The samples included skinless fillets collected from yellow bullhead, golden redhorse, longear sunfish, and channel catfish to reflect the form of fish tissue customarily consumed by anglers. Dorsal fish muscle plugs were collected from largemouth bass for purposes of assessing mercury accumulation. Crayfish tissues were collected for assessing lead accumulation. Upon receipt, the shipment was assigned USGS batch number 1974 and sample identifications (IDs) 55878-55987. All samples had been stored frozen at -20 degrees Celsius $\left({ }^{\circ} \mathrm{C}\right)$ since collection at the MDC's Resource Science Center in Columbia, Missouri, and were delivered by MDC personnel. Requested analyses included zinc ( $\mathrm{Zn})$, cadmium $(\mathrm{Cd})$, mercury $(\mathrm{Hg})$, and lead $(\mathrm{Pb})$. Calcium $(\mathrm{Ca})$ also was analyzed in an effort to explain $\mathrm{Pb}$ variability (Schmitt and Finger, 1987). Fish fillet samples were variable in the way they were obtained, and the fillet technique may have resulted in different amounts of tissue extracted and, thus, may have varying amounts of calcium-rich bone fragments that can be comparatively high in $\mathrm{Pb}$. 


\section{Methods}

\section{Sites and Sample Collection}

In 2011, 16 sites (table 1) were selected for sampling as part of the MDC General Contaminant Monitoring Program (GCMP). The 2011 collection consisted of yellow bullhead (Ameiurus natalis), golden redhorse (Moxostoma erythrurum), longear sunfish (Lepomis megalotis), and channel catfish (Ictalurus punctatus). Besides fish fillet samples collected in 2011, fish dorsal muscle plugs were collected from largemouth bass (Micropterus salmoides), and tissues [tail shell, tail-meat, and carcass (crayfish remains after tail meat was removed or extracted)] were collected from crayfish.

\section{Homogenization and Lyophilization}

GCMP fillet samples were chopped and minced with a titanium meat cleaver on a cleaned polypropylene cutting board and then lyophilized. Fish muscle plugs and crayfish tissues (tail meat and non tail meat) were lyophilized as received. After lyophilization, fish fillet samples were hand-kneaded in a plastic (polyethylene) bag or crushed with a rolling pin in a plastic bag to achieve a coarse powder consistency, whereas crayfish tissues were placed in a glass vial and ground with a glass rod. All dried and ground products were stored at room temperature in a 40 -milliliter $(\mathrm{mL})$ glass vial in a nitrogen desiccator.

\section{Chemical Preparation}

To prepare fish samples for analysis of $\mathrm{Ca}, \mathrm{Zn}, \mathrm{Cd}$, and $\mathrm{Pb}$, a dried sample of approximately 0.25 grams $(\mathrm{g})$ was heated with $6 \mathrm{~mL}$ of nitric acid in a sealed high-pressure Teflon ${ }^{\circledR}$ vessel in a laboratory microwave oven. The cooled digestate liquid was transferred into a $125-\mathrm{mL}$ polyethylene bottle with ultrapure water [specific resistance greater than $(>)$ $10 \mathrm{megOhms}$ per centimeter $(\mathrm{megOhm} / \mathrm{cm})]$ and diluted to a final weight of $101.5 \mathrm{~g}$. Final acid matrix was 6 percent by volume concentrated nitric acid. For the determination of $\mathrm{Hg}$ in fish samples, there was no chemical preparation (digestion) because the dried sample was decomposed thermally during instrumental analysis (see Instrumental Analysis section).

\section{Instrumental Analysis}

Calcium, $\mathrm{Zn}, \mathrm{Cd}$, and $\mathrm{Pb}$ analyses were conducted using a PE/SCIEX Elan 6000® inductively coupled plasma-mass spectrometer (ICP-MS), which was set up in "Standard Mode" and optimized according to the manufacturer's specifications. Samples were delivered automatically to the ICP-MS by means of a software-controlled CETAC ASD-500 autosampler/autodiluter system. All sample digestates were analyzed with a 10 -fold predilution by autodiluter.
The ICP-MS quantitative method was designed to determine the following masses: ${ }^{44} \mathrm{Ca}$ and ${ }^{48} \mathrm{Ca},{ }^{60} \mathrm{Zn}$ and ${ }^{68} \mathrm{Zn},{ }^{111} \mathrm{Cd}$ and ${ }^{114} \mathrm{Cd}$, and $\mathrm{Pb}$ as the sum of three masses $\left({ }^{206} \mathrm{~Pb}+{ }^{207} \mathrm{~Pb}+{ }^{208} \mathrm{~Pb}\right)$. The internal standards were scandium $(\mathrm{Sc})$ at 10 nanograms per milliliter $(\mathrm{ng} / \mathrm{mL})$, rhodium $(\mathrm{Rh}$; $10 \mathrm{ng} / \mathrm{mL}$ ), and bismuth (Bi; $10 \mathrm{ng} / \mathrm{mL}$ ), which were metered into the sample line via peristaltic pump. Calibration standards for analyses were as follows: $\mathrm{Ca}$ - 2500, 5000, and $10,000 \mathrm{ng} / \mathrm{mL} ; \mathrm{Zn}-75,150$, and $300 \mathrm{ng} / \mathrm{mL} ; \mathrm{Pb}-5,10,20$, and $40 \mathrm{ng} / \mathrm{mL}$; and $\mathrm{Cd}-1.5,3.0,6.0$, and $12 \mathrm{ng} / \mathrm{mL}$. During the actual analysis, any digestate concentration greater than the upper calibration standard for any element was automatically diluted 10-fold serially until its concentration was below this level. Where multiple masses for an element were measured, the concentration reported was based on the mass exhibiting least interferences, which were as follows: ${ }^{44} \mathrm{Ca},{ }^{60} \mathrm{Zn},{ }^{114} \mathrm{Cd}$, and $\mathrm{Pb}$ as the sum of three masses ${ }^{206} \mathrm{~Pb}+{ }^{207} \mathrm{~Pb}+{ }^{208} \mathrm{~Pb}$ ).

Mercury was determined with a Milestone DMA-80 analyzer equipped with an automated sample carousel. With this method, a dried fish sample [40 to 60 milligrams (mg)] was combusted in a stream of oxygen. All $\mathrm{Hg}$ in the sample was volatilized and trapped by amalgamation on a gold substrate, and was thermally desorbed and quantitated by atomic absorption spectrophotometry (U. S. Environmental Protection Agency, 1998).

\section{Quality Control}

The samples were digested and analyzed in two groups or batches for $\mathrm{Ca}, \mathrm{Zn}, \mathrm{Cd}$, and $\mathrm{Pb}$, and four batches for $\mathrm{Hg}$. The quality-control incorporated in the digestion stage of the samples (for subsequent ICP-MS analysis) included digestion blanks, reference materials, replicates, and spikes. For the determination of $\mathrm{Ca}, \mathrm{Zn}, \mathrm{Cd}$, and $\mathrm{Pb}$ by ICP-MS, instrumental quality control included calibration checks, laboratory control solutions, duplicate digestate analysis, analysis spikes, and interference checks (dilution percent difference and a synthetic interference solution). Quality control for $\mathrm{Hg}$ included blanks, independent calibration verification checks, replicates, pre-combustion spikes, and tissue reference materials. All quality-control results were tabulated to provide an overview of quality assurance and to facilitate interpretation.

\section{Results}

Percent moisture, concentrations in micrograms per gram $(\mu \mathrm{g} / \mathrm{g})$ dry weight of $\mathrm{Ca}, \mathrm{Zn}, \mathrm{Cd}$, and $\mathrm{Pb}$, and molar ratios (fillet samples only) of $[\mathrm{Pb} / \mathrm{Ca}]\left(1 \times 10^{-6}\right)$ for the fish fillet and crayfish tissues are presented in table 2 . To facilitate comparison with any regulatory guidelines, concentrations of $\mathrm{Ca}, \mathrm{Zn}$, $\mathrm{Cd}$, and $\mathrm{Pb}$ are presented for these matrices in micrograms per gram wet weight in table 3 . Concentrations of total mercury in micrograms per gram dry and wet weight in fish fillets, fish 
Table 1. Missouri collection sites for fish fillets, fish muscle plugs, and crayfish from the 2011 Missouri Department of Conservation General Contaminant Monitoring Program.

\begin{tabular}{|c|c|c|}
\hline Species and Common Name & Sites & Sample Type \\
\hline Ameiurus natalis & Mound Branch at Paxton, Missouri & Fillet \\
\hline \multicolumn{3}{|l|}{ Yellow Bullhead } \\
\hline Moxostoma erythrurum & Big River at House Springs & Fillet \\
\hline \multirow[t]{2}{*}{ Golden Redhorse } & Meramec River at Allenton Access & Fillet \\
\hline & Meramec River at Route 66 State Park & Fillet \\
\hline Lepomis megalotis & Meramec River at Allenton Access & Fillet \\
\hline \multirow[t]{2}{*}{ Longear Sunfish } & Big River at House Springs & Fillet \\
\hline & Meramec River at Route 66 State Park & Fillet \\
\hline Ictalurus punctatus & Wakonda State Park at Agate Lake & Fillet \\
\hline Channel Catfish & Wakonda State Park at Wakonda Lake & Fillet \\
\hline Micropterus salmoides & Lake of the Ozarks at Niangua Arm & Plug \\
\hline \multirow[t]{7}{*}{ Largemouth Bass } & Longview Lake & Plug \\
\hline & Stockton Lake at Big Sac Arm & Plug \\
\hline & Clearwater Lake & Plug \\
\hline & Lake St. Louis & Plug \\
\hline & Noblett Lake & Plug \\
\hline & Hazel Creek Lake & Plug \\
\hline & Harrison County Lake & Plug \\
\hline \multirow[t]{5}{*}{ Crayfish species } & Big River at Cherokee Landing & Tail meat \\
\hline & & Non tail meat \\
\hline & Shoal Creek 0.5 mile North of I-44 Bridge & Tail meat \\
\hline & & Non tail meat \\
\hline & & Tail shell \\
\hline
\end{tabular}

muscle plugs, and crayfish tissues are presented in table 4. For this report all sample and quality-control data are discussed in terms of dry weight results only.

Calcium concentrations were variable among fillet samples; concentrations were generally within a factor of two or three among golden redhorse, but increased to a factor of seven in longear sunfish (table 2). Such variation presumably was because of variable bone content in the fillets and undoubtedly was affected by significant variations in fillet preparation techniques as well as by the fish species. For example, catostomids possess numerous tiny intermuscular bones. Accordingly, fillets from some species (golden redhorse and longear sunfish) contained higher $\mathrm{Ca}$ concentrations than other species (catfish). Although Ca normally is not a target analyte, fillet $\mathrm{Ca}$ concentrations are useful when target analytes include those that markedly accumulate in bone (for example, $\mathrm{Pb}$ ). Thus, measurements of $\mathrm{Ca}$ can help explain high variation in $\mathrm{Pb}$ concentrations for individual samples that included variable amounts of Ca-rich tissue (Schmitt and Finger, 1987). Concentrations of $\mathrm{Ca}$ in crayfish tail-meat were similar to those of fish fillets, but concentrations in crayfish carcass remains and shell samples were some 100 fold higher.

Zinc concentrations were quite uniform in fillet samples among the different species of fish, ranging from 20 to $31 \mu \mathrm{g} / \mathrm{g}$ dry weight. Concentrations of $\mathrm{Zn}(\mu \mathrm{g} / \mathrm{g}$ dry weight) in crayfish tissues were lowest in tail shell samples (17 to 25), but three to six fold higher in tail meat and carcass samples (71 to 134). Cadmium concentrations ( $\mu \mathrm{g} / \mathrm{g}$ dry weight) were less than 0.1 in most fish fillet samples ( 72 percent of sample set) and ranged from 0.1 to 0.26 in remaining fillet samples. Cadmium 


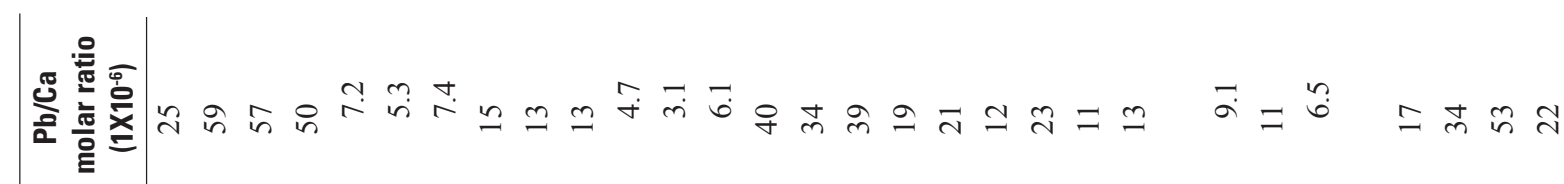

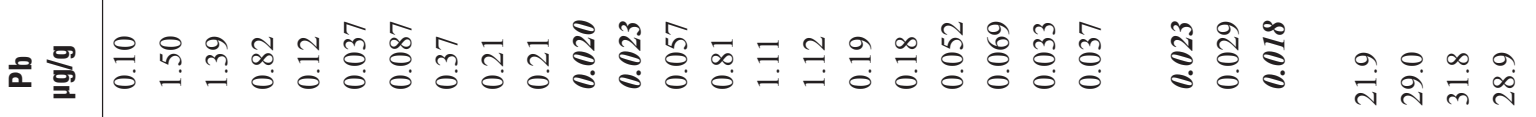

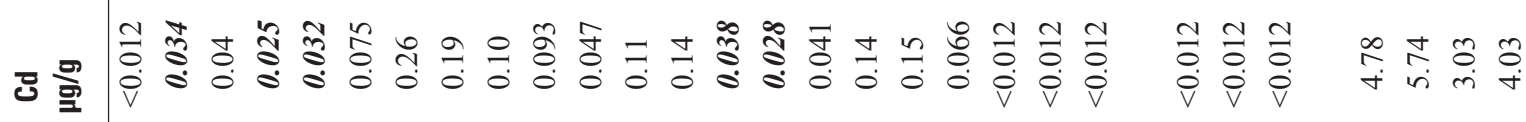

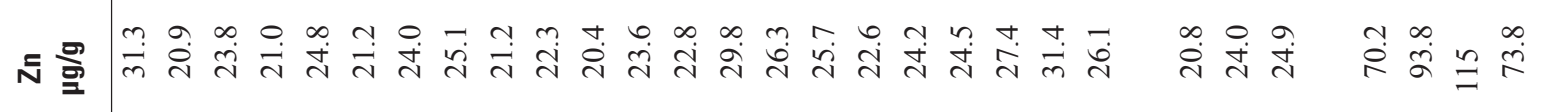

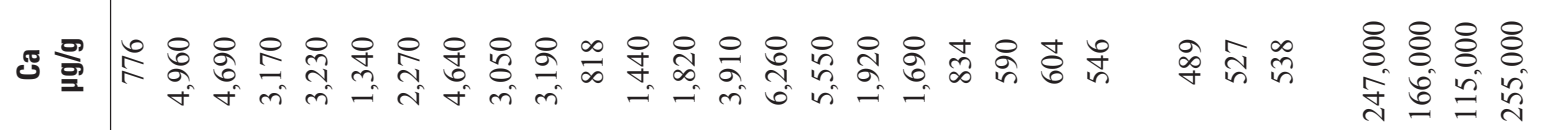

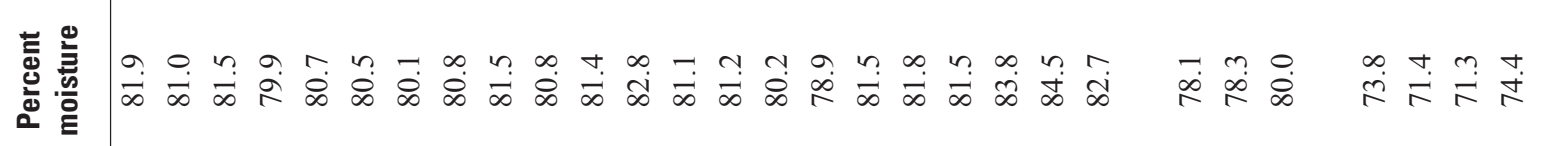

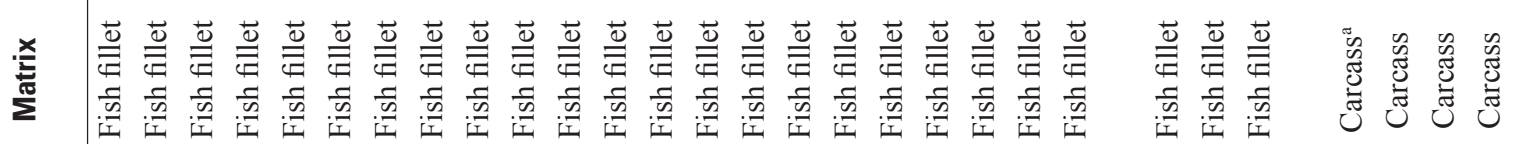

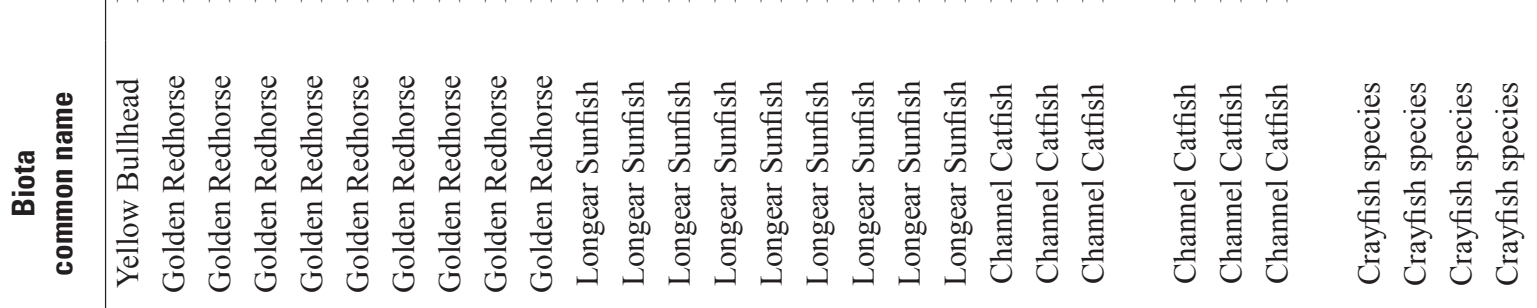

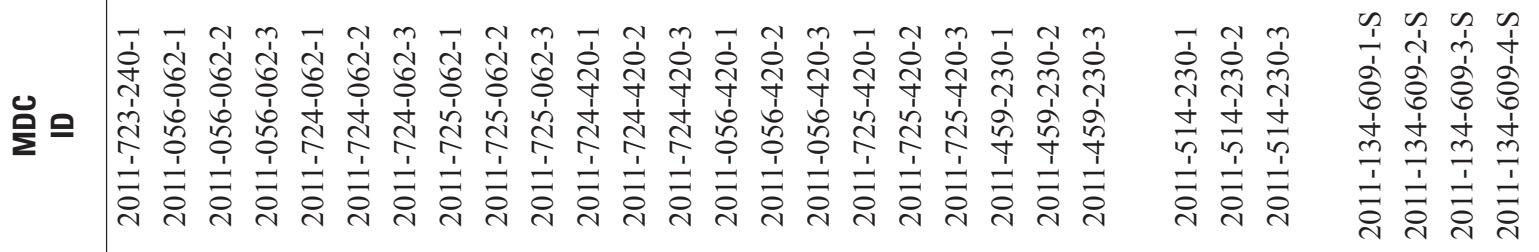

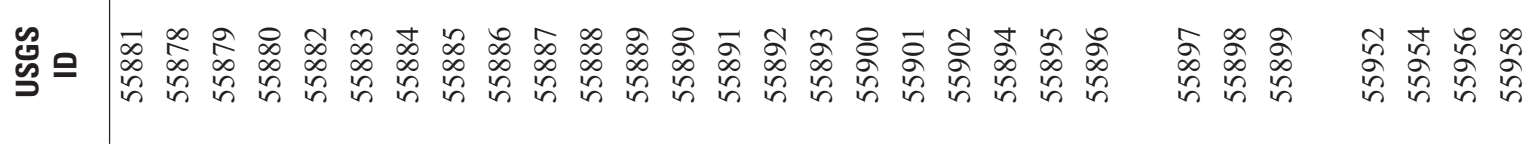




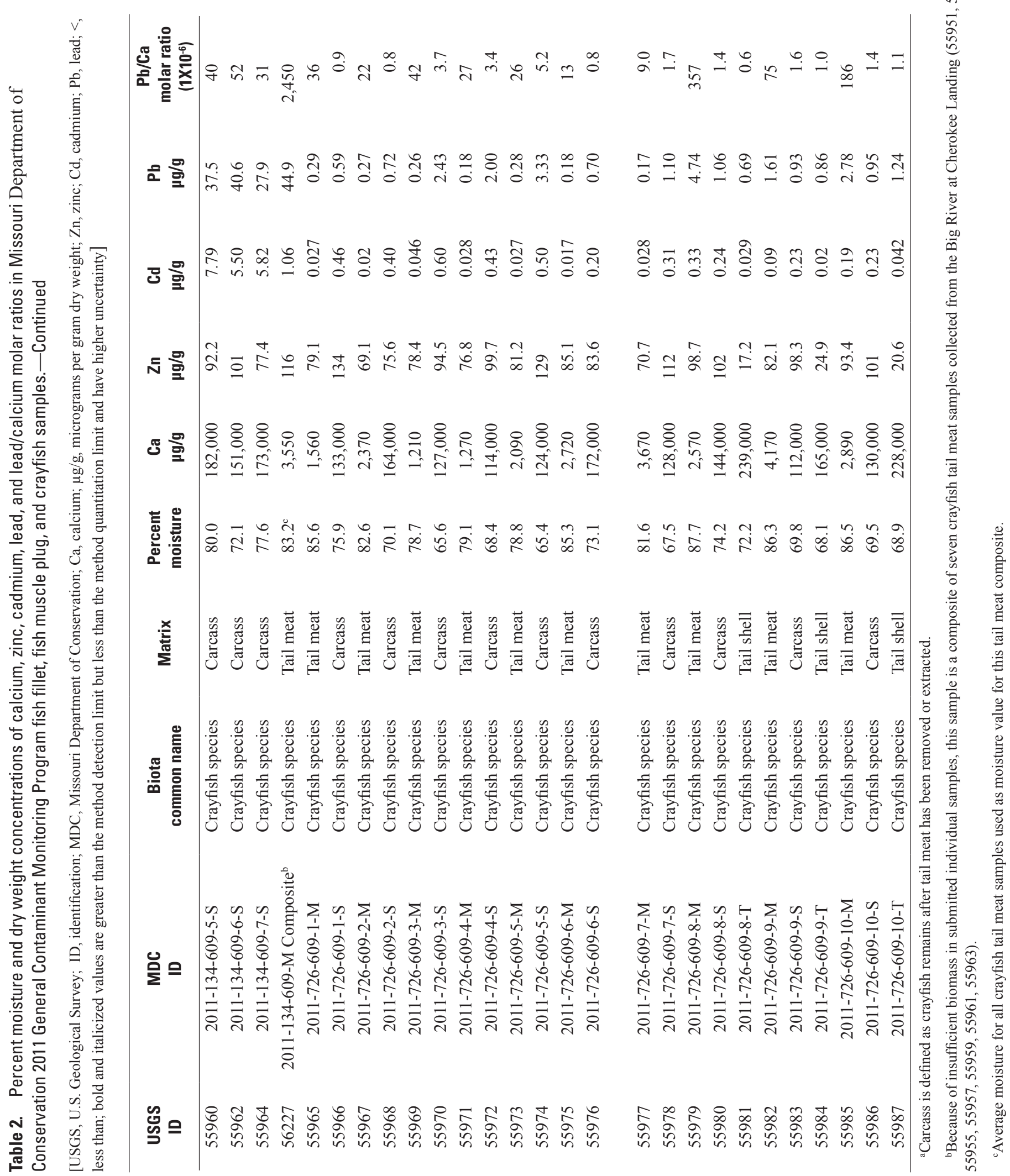




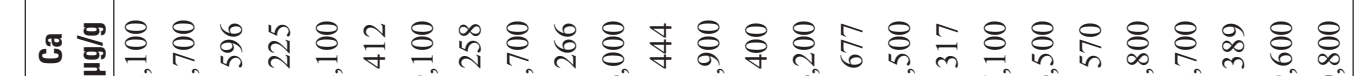

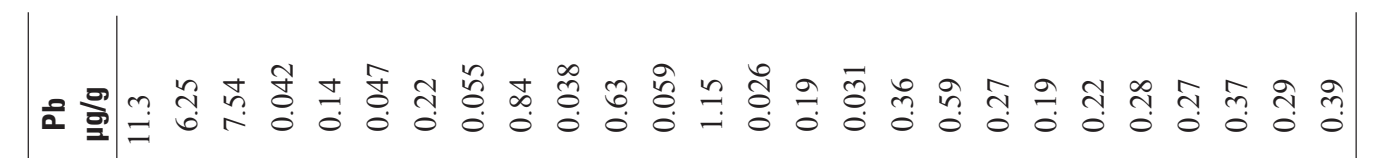

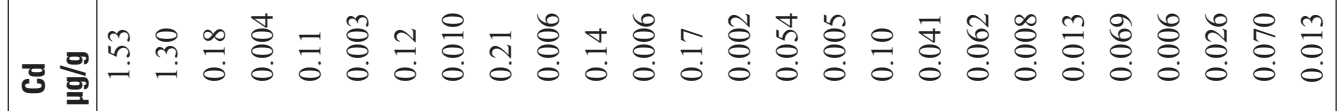
ف

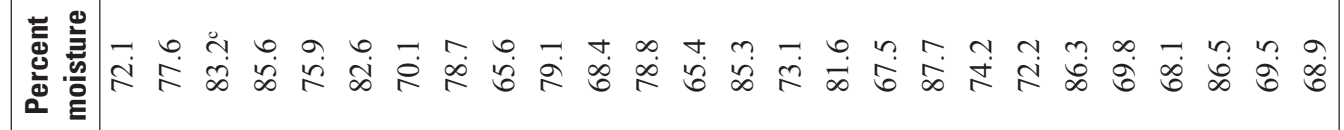

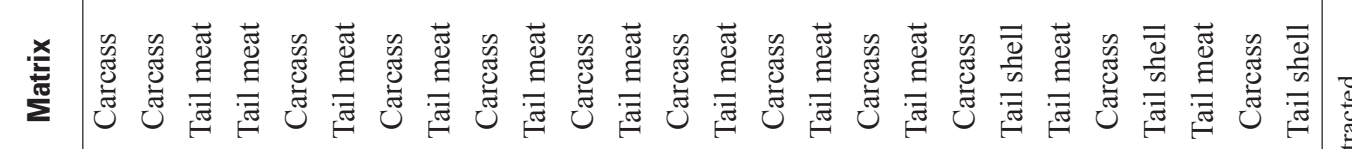

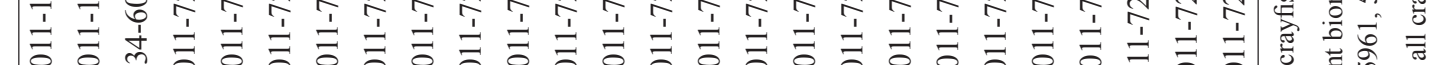
잉 


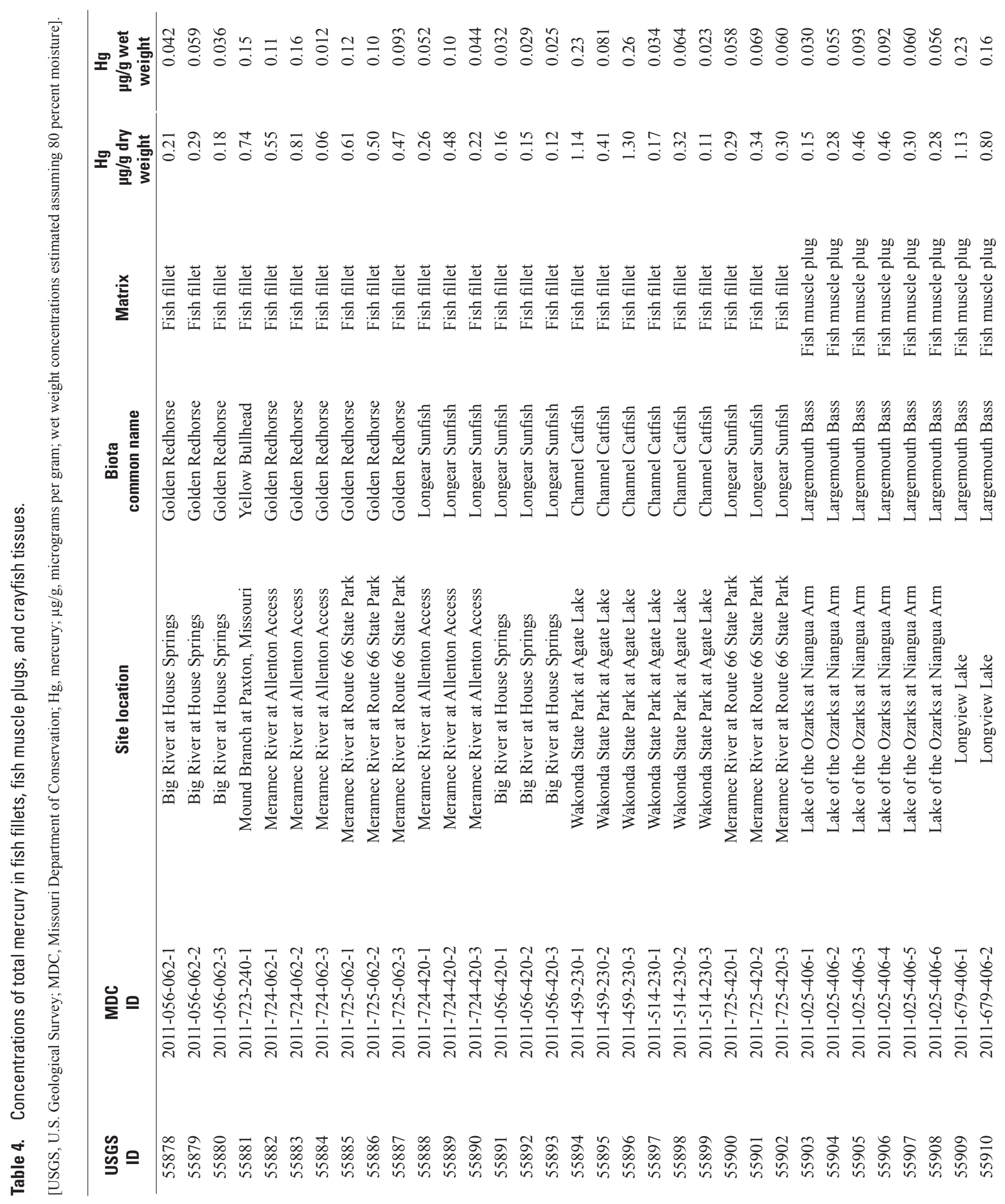




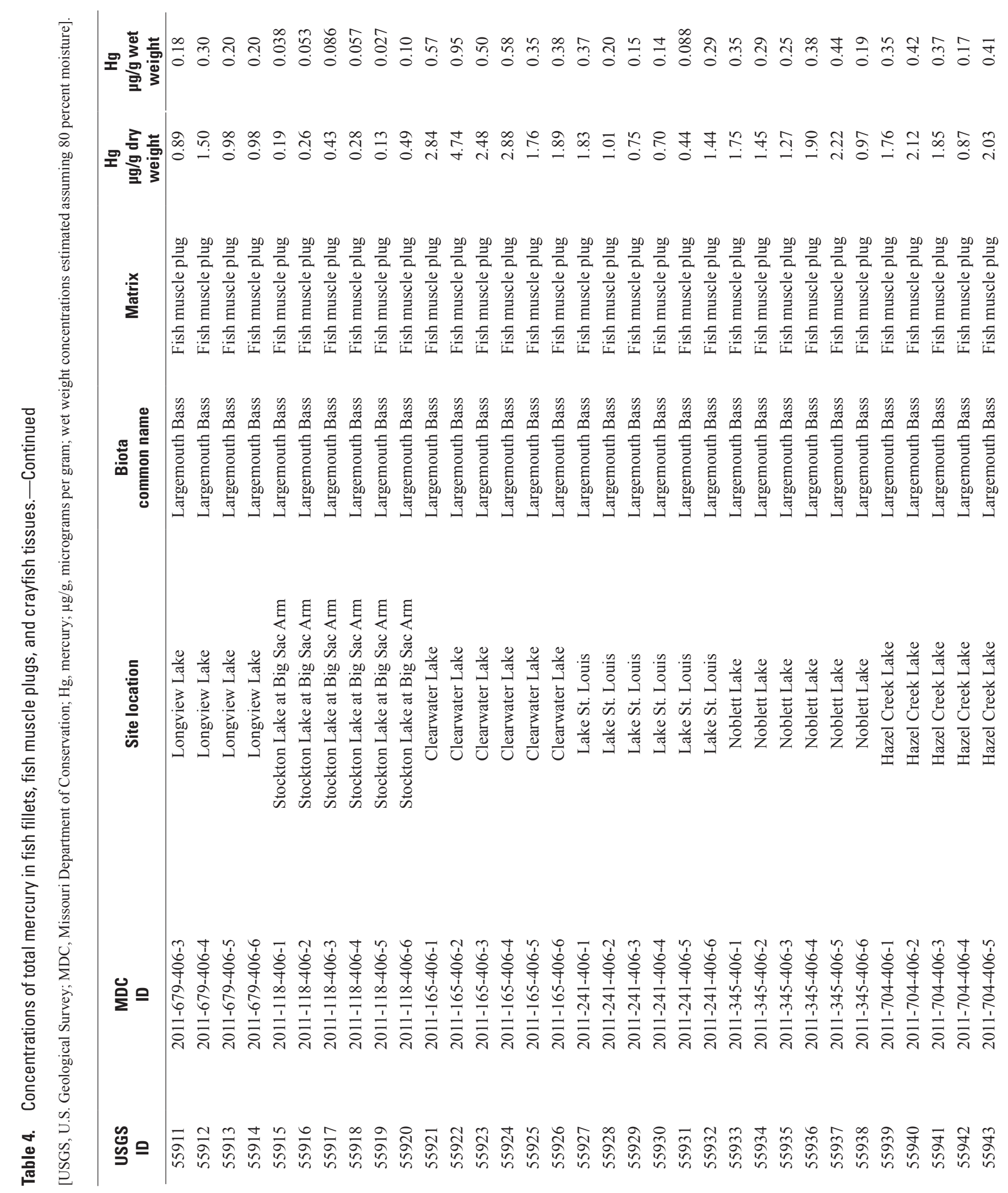




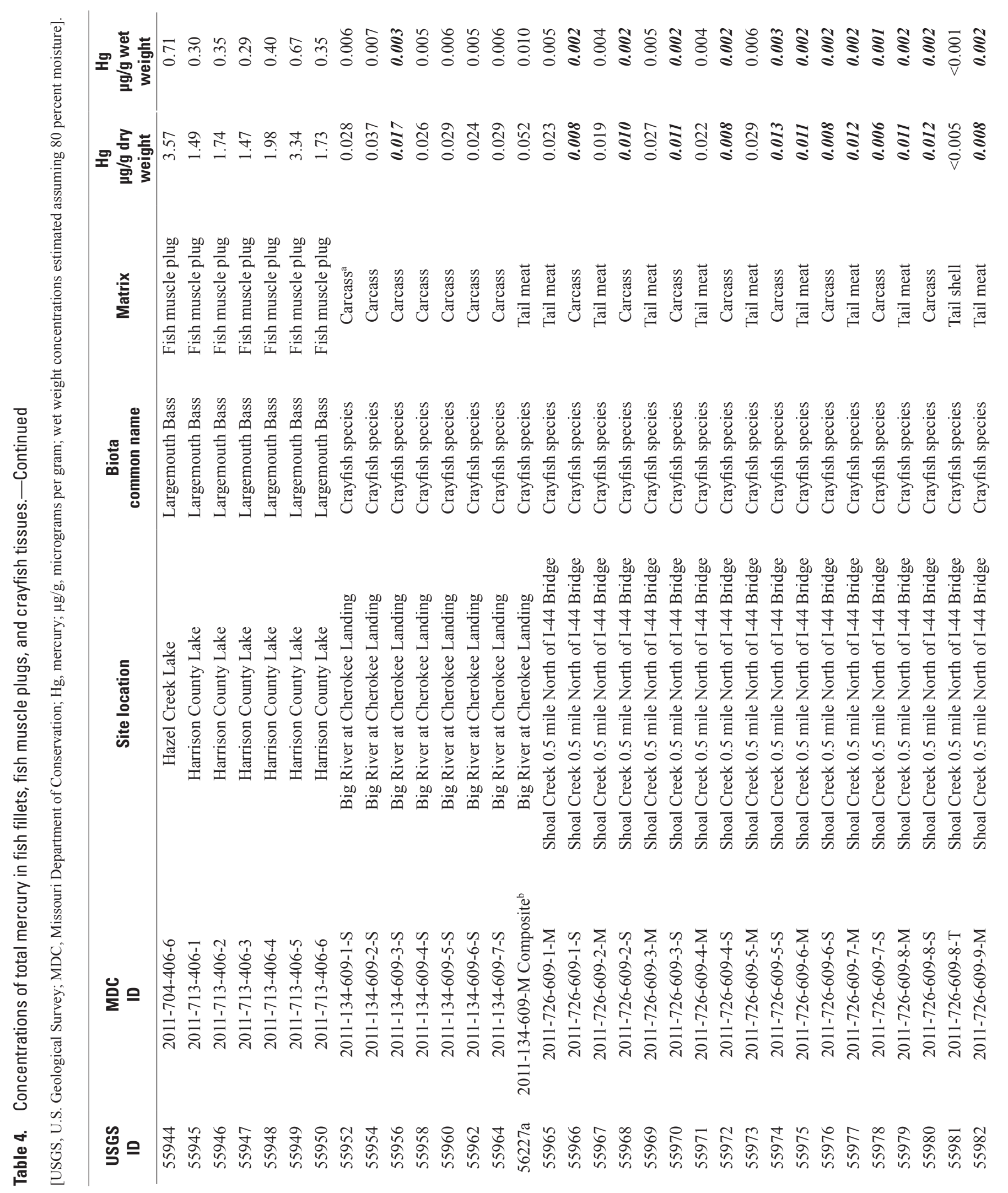


levels were markedly higher in crayfish carcass samples from the Big River at Cherokee Landing (3 to $7.8 \mu \mathrm{g} / \mathrm{g}$ dry weight; USGS IDs 55952-55964) and tail-meat levels were most elevated in the tail meat composite sample from this site (1.06 $\mu \mathrm{g} / \mathrm{g}$ dry weight; USGS ID 56227). Cadmium concentrations ( $\mu \mathrm{g} / \mathrm{g}$ dry weight) in crayfish tissues collected from the one remaining site (Shoal Creek; USGS IDs 55965-55987) ranged as follows: carcass, 0.2 to 0.5 ; tail shell, 0.02 to 0.042 ; and tail meat, 0.017 to 0.33 . Lead concentrations $(\mu \mathrm{g} / \mathrm{g}$ dry weight) in fish fillet samples mostly were less than 0.5 (76 percent of the sample set), whereas remaining samples ranged from 0.81 to 1.5. All crayfish tissues from Shoal Creek exhibited $\mathrm{Pb}$ concentrations ranging from 0.17 to $4.74 \mu \mathrm{g} / \mathrm{g}$ dry weight. This is in sharp contrast to $\mathrm{Pb}$ concentrations in crayfish carcass samples and a tail meat composite in crayfish collected from Cherokee Landing (21.9 to $44.9 \mu \mathrm{g} / \mathrm{g}$ dry weight).

All fish fillet samples exhibited $\mathrm{Hg}$ concentrations less than the current (2009) U. S. Environmental Protection Agency (USEPA) Water Quality Criterion for $\mathrm{Hg}$ of $0.30 \mu \mathrm{g} / \mathrm{g}$ wet weight (table 4), or about $1.5 \mu \mathrm{g} / \mathrm{g}$ dry weight based on an 80 percent moisture content (U. S. Environmental Protection Agency, 2001); however, a number of dorsal fish muscle plugs collected from largemouth bass exceeded this criterion, and the site, number of plugs, and $\mathrm{Hg}$ concentration ranges $(\mu \mathrm{g} / \mathrm{g}$ dry weight) were as follows: Clearwater Lake, 6 plugs, 1.76 to 4.74; Lake St. Louis, 1 plug, 1.83; Noblett Lake, 3 plugs, 1.75 to 2.22; Hazel Creek Lake, 5 plugs, 1.76 to 3.57; Harrison County Lake, 4 plugs, 1.73 to 3.34. Mercury concentrations in all crayfish tissues were quite low (less than $0.06 \mu \mathrm{g} / \mathrm{g}$ dry weight).

\section{Quality-Control Results}

Calibration Verification.-A calibration blank and an independent calibration verification standard (ICVS) were analyzed every 10 samples to confirm the calibration status of the ICP-MS during instrumental analyses of the fish fillets, fish muscle plugs, and crayfish tissues for $\mathrm{Ca}, \mathrm{Zn}, \mathrm{Cd}$, and $\mathrm{Pb}$; blanks were within plus or minus ( \pm )three times the instrument detection limits for each element, and ICVS recoveries were within the target of 90 to 110 percent of the ICVS standard concentration for each element. Three reference solutions [National Institute of Standards and Technology (NIST) Standard Reference Material (SRM) 1640a: Trace Elements in Natural Water; Spex ClaritasPPT Instrument Check Standard 1 (Spex ICS-1); and High Purity Standards Certified Reference Solution Trace Metals in Fish: HP CRM-TF] used as laboratory-control samples exhibited elemental recoveries ranging from 98 to 100 percent. Calibration verification reference tissues for total $\mathrm{Hg}$ [National Research Council Canada (NRCC) DOLT-3: Dogfish Liver; International Atomic Energy Agency (IAEA) 407-Trace Elements and Methylmercury in Fish Tissue] were analyzed at the beginning and end of 
the instrumental runs to confirm the calibration status of the DMA-80 system; percent errors were within the target of \pm 10 percent.

Reference Materials. - Recoveries of $\mathrm{Ca}, \mathrm{Zn}, \mathrm{Cd}$ and $\mathrm{Pb}$ in three tissue reference materials (NIST 1566a: Oyster Tissue, $n=1$; IAEA 407: Whole-body Fish, $n=1$; NRCC TORT-1: Lobster Hepatopancreas, $\mathrm{n}=1$ ) ranged from 80 to 120 percent and averaged 100 percent. Recoveries of $\mathrm{Hg}$ from six different tissue reference materials (IAEA MA-A-1: Copepod, $n=4$; IAEA MA-A-2: Fish Flesh Homogenate, n=4; IAEA 407: Whole-body Fish, $n=4$; NIST RM50: Albacore Tuna, $n=1$; NRCC DOLT-3: Dogfish Liver, $\mathrm{n}=4$; and NRCC DORM-2: Dogfish Fillet, $\mathrm{n}=4$;) ranged from 89 to 105 percent and averaged 98 percent.

Method and Instrumental Precision.- Method precision as estimated from measurement variation for triplicate digestion and analysis of a fish fillet sample had percent relative standard deviations (PRSDs) for $\mathrm{Ca}, \mathrm{Zn}$, and $\mathrm{Cd}$ that were less than or equal to $(\leq) 26$, but 60 for $\mathrm{Pb}$; however, the higher variation for $\mathrm{Pb}$ was not considered unusual because two of the three sample concentrations were below the method quantitation limit of $0.026 \mu \mathrm{g} / \mathrm{g}$ dry weight. PRSDs for the elements from a crayfish carcass replicate were $\leq 10$. Relative percent differences (RPDs) from the duplicate digestion and analysis of the crayfish tail meat composite sample were $\leq 21$ for $\mathrm{Ca}, \mathrm{Zn}$, and $\mathrm{Pb}$, but higher (40) for $\mathrm{Cd}$. All PRSDs for $\mathrm{Hg}(\mathrm{n}=4)$ were less than $(<) 9$ percent. Instrumental precision measured as RPD from the analysis of fish fillet $(n=3)$ and crayfish tail meat $(\mathrm{n}=3)$ duplicate digestates for $\mathrm{Ca}, \mathrm{Zn}, \mathrm{Cd}$, and $\mathrm{Pb}$ was $<5$ percent.

Spikes.- Recoveries of $\mathrm{Zn}, \mathrm{Cd}$, and $\mathrm{Pb}$ spiked into fish tissue $(\mathrm{n}=2)$ ranged from 105 to 107 percent and averaged 106 percent, whereas Ca spike recoveries were 111 and 145 percent. Recoveries of all four elements in spiked crayfish tissues $(\mathrm{n}=2)$ ranged from 103 to 120 percent and averaged 111 percent. Recoveries of methylmercury hydroxide spiked into fish fillet $(\mathrm{n}=2)$, fish muscle plugs $(\mathrm{n}=4)$, and crayfish tissue $(n=2)$ ranged from 70 to 101 percent and averaged 88 percent. Post-digestion or analysis spikes for $\mathrm{Ca}, \mathrm{Zn}, \mathrm{Cd}$, and $\mathrm{Pb}$ in fish fillets $(n=3)$ and crayfish tissues had recoveries ranging from 81 to 105 percent and averaged 96 percent.

Interference Checks.- As a check for potential interferences, dilution percent differences (DPDs) based on fivefold dilutions of fish fillet $(\mathrm{n}=3)$ and crayfish tail-meat digestates were determined. DPDs were $\leq 11$ percent for $\mathrm{Zn}, \mathrm{Cd}$, and $\mathrm{Pb}$, but higher for $\mathrm{Ca}$ (14 to 27 percent), suggesting some suppression of the $\mathrm{Ca}$ signal in these matrices. A synthetic solution containing high concentrations of aluminum, $\mathrm{Ca}$, iron, magnesium, sodium, phosphorus, potassium, sulfur, carbon, molybdenum, and titanium was analyzed $(n=4)$ to observe the effects of these potential interfering elements on the determination of $\mathrm{Zn}, \mathrm{Cd}$, and $\mathrm{Pb}$ concentrations in this matrix. Recoveries were within the 80 to 120 percent tolerance

Blank Equivalent Concentrations (BEC).-BECs ( $\mu \mathrm{g} / \mathrm{g}$ dry weight, $\mathrm{Ca}, \mathrm{Zn}, \mathrm{Cd}, \mathrm{Pb}$ ) for digestion blanks prepared with each batch were determined; all BECs were less than the corresponding method detection limits (MDLs) except for one instance of $\mathrm{Zn}(0.16 \mathrm{BEC}$ compared to $0.11 \mu \mathrm{g} / \mathrm{g} \mathrm{MDL})$, one instance of Cd (0.002 BEC compared to $0.002 \mu \mathrm{g} / \mathrm{g}$ MDL), and one instance of $\mathrm{Pb}(0.009 \mathrm{BEC}$ compared to $0.007 \mu \mathrm{g} / \mathrm{g}$ MDL). The BEC exceptions each represent low concentrations that were not considered unusual. All BECs for $\mathrm{Hg}$ were less than the corresponding $\mathrm{Hg}$ MDLs

Instrument Detection, Method Detection, and Method Quantitation Limits.-The instrument detection limit (IDL) for $\mathrm{Hg}$ was 0.002 nanograms (ng); the IDLs for other target analytes in nanograms per milliliter were as follows: $\mathrm{Ca}, 2.3$; $\mathrm{Zn}, 0.9$; $\mathrm{Cd}, 0.003$; and $\mathrm{Pb}, 0.004$. MDLs were computed in $\mu \mathrm{g} / \mathrm{g}$ dry weight for each batch of samples as:

$$
3 \mathrm{X}\left(\mathrm{SD}_{\mathrm{b}}^{2}+\mathrm{SD}_{\mathrm{s}}^{2}\right)^{1 / 2}
$$

where

$$
\begin{aligned}
\mathrm{SD}_{\mathrm{b}}= & \text { standard deviation of a blank }(\mathrm{n}=3) ; \text { and } \\
\mathrm{SD}_{\mathrm{s}}= & \text { standard deviation of a low level sample or } \\
& \text { spiked sample }(\mathrm{n}=3)
\end{aligned}
$$

and were as follows: $\mathrm{Ca}, 1.6$ to $2.9 ; \mathrm{Zn}, 0.03$ to 0.6 ; $\mathrm{Cd}, 0.002$ to $0.012 ; \mathrm{Hg}, 0.005$ to 0.042 ; and $\mathrm{Pb}, 0.007$ to 0.009 . Method quantitation limits (MQLs) were calculated in $\mu \mathrm{g} / \mathrm{g}$ dry weight as $3.3 \times$ MDLs and were as follows: $\mathrm{Ca}, 5.3$ to $9.6 ; \mathrm{Zn}, 0.1$ to 2.0; $\mathrm{Cd}, 0.007$ to $0.040 ; \mathrm{Hg}, 0.018$ to 0.14 ; and $\mathrm{Pb}, 0.023$ to 0.030 .

All quality-control results for the study were within acceptable limits as specified by USGS.

\section{References Cited}

Schmitt, C.J., and Finger, S.E., 1987, The effects of sample preparation on measured concentrations of eight elements in edible tissues of fish from streams contaminated by lead mining: Archives of Environmental Contamination and Toxicology, v.16, p.185-207.

U. S. Environmental Protection Agency, 1998, Mercury in solids and solutions by thermal decomposition, amalgamation, and atomic absorption spectrophotometry: accessed August 28, 2007, at http://www.epa.gov/epaoswer/hazwaste/ test/up4a.htm\#7_series.

United States Environmental Protection Agency, 2001, Water quality criterion for protection of human health - Methylmercury: Washington D.C., U. S. Environmental Protection Agency, Office of Water, EPA-823-R-01-001, 16 p. 
Publishing support provided by:

Rolla Publishing Service Center

For more information concerning this publication, contact:

Director, USGS Columbia Environmental Research Center 4200 New Haven Road

Columbia, MO 65201

(573) 875-5399

Or visit the Columbia Environmental Research Center Web site at: http://www.cerc.usgs.gov/ 
